\title{
MYCOCHEMICAL SCREENING, ANTIOXIDANT AND DNA PROTECTING ACTIVITY OF PENICILLIUM CYCLOPIUM AND PENICILLIUM BREVICOMPACTUM
}

\author{
VIOLETA D. JAKOVLJEVIĆ ${ }^{1 *}$, JASMINA M. NIKOLIĆ ${ }^{1}$, SANJA L.J. MATIĆ ${ }^{1}$, SNEŽANA M. \\ STANIĆ ${ }^{1}$, MIROSLAV M. VRVIĆ ${ }^{2}$ \\ ${ }^{I}$ Institute for Biology and Ecology, Faculty of Science, University of Kragujevac, Radoja Domanovića 12, 34 000, Kragujevac, \\ Serbia \\ ${ }^{2}$ Department of Biochemistry, Faculty of Chemistry, University of Belgrade, Studentski trg 12-16, 11000, Belgrade, Serbia
}

*corresponding author: jakovljevicvioleta@gmail.com

Manuscript received: July 2016

\begin{abstract}
The mycochemical screening, antioxidant potential and DNA protecting potential of Penicillium cyclopium and Penicillium brevicompactum were in the focus of this study. The ethanolic extracts of mycelia were used for the evaluation of their antioxidant potential by the following assays: 2,2-diphenyl-1-picrylhydrazyl (DPPH) free-radical scavenging activity, total antioxidant capacity, $\mathrm{Fe}^{2+}$-chelating activity, $\mathrm{Fe}^{3+}$-reducing capacity and DNA protection against hydroxyl radical damage. The mycochemical analysis of the extracts revealed the presence of phenols, terpenoids, alkaloids, tannins, carbohydrates and amino acids. The ethanolic extract of $P$. cyclopium contained higher amounts of phenolic compounds and ferrous ion chelating ability. P. brevicompactum showed higher total antioxidant capacity, DPPH free-radical scavenging and reducing power ability. Both ethanolic extracts of mycelia showed excellent ability to reduce the hydroxyl radical-induced DNA damage. Thus, both Penicillium species can be considered as promising source of natural antioxidants.
\end{abstract}

\section{Rezumat}

Studiul a urmărit analiza compoziției chimice, potențialul antioxidant și de protecție al ADN-ului pentru speciile Penicillium cyclopium și Penicillium brevicompactum. Extractele etanolice micelare au fost utilizate pentru evaluarea potențialului antioxidant prin următoarele teste: 2,2-difenil-1-picrilhidrazil (DPPH), capacitatea antioxidantă totală, activitatea de chelatare a $\mathrm{Fe}^{2+}$, capacitatea de reducere a $\mathrm{Fe}^{3+}$ şi protecţia ADN împotriva radicalilor liberi hidroxil. Analiza extractelor a evidenţiat prezența fenolilor, a terpenoidelor, alcaloizilor, taninurilor, carbohidraților și aminoacizilor. Extractul etanolic de $P$. cyclopium conține cantități mai mari de compuși fenolici și o capacitate mai mare de captare a radicalilor liberi DPPH și o putere reducătoare mai mare. Ambele extracte etanolice micelare au demonstrat efect protector asupra ADN-ului, fiind surse promițătoare de antioxidanți naturali.

Keywords: DNA protecting activity, DPPH scavenging activity, $\mathrm{Fe}^{2+}$-chelating activity, $\mathrm{Fe}^{3+}$-reducing capacity

\section{Introduction}

Fungi of the genus Penicillium are the most widespread in nature. They are generally saprophytic organisms but may also be parasites of plants, animals and humans. They inhabit a variety of ecological niches: water, soil, air; nutritious foods, decaying organic waste. Due to their ability to break down various xenobiotics, they have a significant role in bioremediation processes [25]. In addition, a large number of primary metabolites of genus Penicillium (proteins, enzymes - ribonuclease, protease, and lipase) are used in biotechnology [10]. In the last years, these fungi have been in focus for a great number of pharmaceutical and medicinal studies which have been directed toward the identification of natural secondary metabolites with antioxidant activity, as an alternative to synthetic antioxidants [32]. Unlike synthetic antioxidants, which are phenolic compounds with varying degrees of alkyl substitution, natural antioxidants can be phenolic compounds (amino acids, alkaloids, peptides and amines), carotenoids, tocopherol or ascorbic acid and its derivates [8]. They demonstrate a variety of bioactivities along with antioxidant properties and function depending on their structure [30]. The oxidative damage of DNA is one of the most important mechanisms in the initiation of cancer. Iron is believed to be the metal responsible for the creation of hydroxyl radicals because it exists at the highest concentration of any transition metal in most living organisms.

The highly reactive hydroxyl radical reacts with the heterocyclic DNA bases and the sugar moiety near, or at diffusion-controlled rates, potentially causing a plethora of lesions that can be cytotoxic or mutagenic. The hydroxyl radical interacts with the $\mathrm{C}-8$ of guanine (8-oxoguanine), which is one of the most commonly found oxidized bases, in the DNA structure. Several 
oxidized products of bases and sugar moieties such as 5-OH cytidine, hypoxanthine, oxidized deoxyribose, formamidopyrimidine, fragmented thymine and thymine glycol, etc., are formed and they are all capable of stalling the replicative and transcriptional processes. The activity of these radicals can be reduced by natural antioxidants found in plants. Generally, two possible approaches exist for protecting DNA oxidative damage by natural antioxidants: one is to scavenge $\cdot \mathrm{OH}$, then to reduce its attack; the other is to enhance the repair mechanisms of deoxy nucleotide radical cations which were damaged by -OH. Intensive researches of cytotoxicity induced by hydrogen peroxide during the last 20 years have shown that different phenols and flavonoids can suppress this process [9]. Thus, quercetin and myricetin [18], gallic acid [34], hesperidin [15], coumarin [3] can protect DNA from oxidative stress-induced damage in vitro. Phenolic compounds, which possess aromatic rings and double bonds, can pass through the cell membrane [26] and react with hydroxyl radicals to form an addition product, and thus scavenge the $\cdot \mathrm{OH}$ directly. A recent study [7] has shown that phenolic compounds from extracts of $C$. pinnatifida pollen possess phenolic hydroxyl groups, which may chelate the ferrous ion and decrease the formation of hydroxyl radicals generated from Fenton's reaction. Moreover, literature data [18] show that pyrogallol and myricetin exhibit a scavenging effect on hydrogen peroxide in vitro. As already known, filamentous fungi have a remarkable ability of chelation of metal ions, therefore it is expected that the tested fungi are capable of preventing the generation of $\cdot \mathrm{OH}$ by Fenton reaction. By screening a large number of Penicillium isolates, about 100 producer strains and tens of secondary metabolites were identified. Among the major natural products synthesized by these fungi, such biologically active compounds as ergot alkaloids, diketopiperazones and quinoline alkaloids are of special interest. They are biogenetically related to shikimate pathway of amino acids biosynthesis, especially to anthranilate and tryptophan [35]. According to literature data, most of the investigated Penicillium isolates are originating from soil samples $[1,6]$, whereas only a few of them are originating from water samples $[11,13]$. Recent investigations on marine filamentous fungi looking for biologically active secondary metabolites indicate the tremendous potential of them as, a source of new medicines [13]. Wastewaters contain various organic substances, which are the products of human activity. Many fungi are allochthonous inhabited wastewater and they have developed an efficient system of defence against free radicals during evolution. Accordingly, it is expected an effective antioxidant activity and a good potential for the synthesis of new natural antioxidants. In line with this presumption, the previous research [13] carried out on $P$. chrysogenum and $P$. funiculosum, isolated from sewage wastewater, showed that the mentioned fungi could be considered as source of natural antioxidants. To the best of our knowledge, no study has been conducted aiming to investigate the antioxidant and DNA protecting potential of $P$. cyclopium and $P$. brevicompactum so far. Therefore, the current study was designed in order to determine the mycochemical constituents and to investigate the relationship between the total phenolics and the antioxidant properties of fungi through different antioxidant assays. These data will provide some useful information for healthier living and further screening of fungi as potential sources of new natural antioxidants.

\section{Materials and Methods}

Isolation of fungi from wastewater and determination The fungi species were isolated from wastewaters originating from households which flow directly into the River basin of Great Morava (Ćuprija town, Serbia) and Western Morava (Čačak town, Serbia). Samples of wastewater were collected in a sterile container, transferred to the microbiology laboratory and deposited in a refrigerator at $4{ }^{\circ} \mathrm{C}$. Within 24 hours, different dilutions of the samples were transferred on Petri plates with malt agar and streptomycin to prevent bacterial growth. The plates were maintained at room temperature for 5 days. Positive cultures were sub-cultured on malt agar and potato dextrose agar for the isolation of a pure, single colony for identification. The identification of fungi $P$. cyclopium Westling (1910) and $P$. brevicompactum Dierckx (1901) was based primarily on the macroscopic and microscopic morphology and was carried out by Systematic keys at the Institute of Biology and Ecology, Faculty of Science, Kragujevac. The fungi were maintained on potato-dextrose-agar (PDA) slant, grown at $30^{\circ} \mathrm{C}$, stored at $4 \pm 0.5^{\circ} \mathrm{C}$, and subculture monthly in sterile conditions.

Cultivation of fungi and extraction of mycelia

The Erlenmeyer flasks containing $100 \mathrm{~mL}$ of liquid potato dextrose broth (PDB) medium were sterilized at $121{ }^{\circ} \mathrm{C}$ for $20 \mathrm{~min}$. After cooling to room temperature, the liquid media were inoculated with $1 \mathrm{~mL}$ spore suspension $\left(1 \times 10^{4} \mathrm{CFU} / \mathrm{mL}\right)$ and incubated at room temperature with occasional stirring. After five days of incubation, mycelia were separated from the fermentation broth by filtration through Whatman filter paper no. 1. Mycelia were dried at $50^{\circ} \mathrm{C}$ to constant weight and then were pulverized and extracted with $200 \mathrm{~mL} \mathrm{96 \%} \mathrm{ethanol}$ $(1: 1, \mathrm{v} / \mathrm{v})$ three times. The supernatant was separated by centrifugation at 5,000 rpm for $10 \mathrm{~min}$, fractions were pooled and the ethanolic extract was concentrated under reduced pressure to yield the final extract. The obtained mycelial extracts were stored in dark at $4{ }^{\circ} \mathrm{C}$. 
Qualitative mycochemical screening of extracts The crude mycelial extracts were used for qualitative determination of major myco-constituents, such as phenols [28], flavonoids [28], steroids [24], tannins [12], alkaloids [28], amino acids [27] and carbohydrates [27] using different methods previously described.

Quantitative determination of total phenolic contents The total phenolic compounds in the extracts were determined colorimetrically using the Folin-Ciocâlteu (FC) method according to procedure described by Madaan et al. [17]. The total phenolic content in the extracts was expressed as gallic acid equivalent in $\mathrm{mg} / \mathrm{g}$ (GAE mg/g extract).

In vitro antioxidant assay

A stock solution of at $4 \mathrm{mg} / \mathrm{mL}$ was maintained for the both fungal extracts. The stock solutions of the extracts were diluted with methanol to obtain serial dilutions with the following concentrations: 0.016 , $0.031,0.062,0.125,0.250,0.500$ and $1 \mathrm{mg} / \mathrm{mL}$ for performing various antioxidant assays and assessing the reducing ability. The antioxidant power of the extracts obtained by using different antioxidant assays was compared with that of the standard antioxidant compounds.

Total antioxidant activity

The total antioxidant activity was determined by phosphomolybdenum method according to procedure by Jakovljevic et al. [13]. The total antioxidant activity of the extracts was expressed as the ascorbic acid equivalent in $\mu \mathrm{g} / \mathrm{g}$ (AA $\mu \mathrm{g} / \mathrm{g}$ extract).

DPPH radical scavenging assay

The antiradical activity of the extracts was estimated according to the procedure described by Olugbami et al. [22]. The DPPH radical scavenging effect (\%) of extracts and standards: AA, GA, butylated hydroxytoluene (BHT), $\alpha$-tocopherol and quercetin were determined according to Equation 1:

$$
\% \text { Inhibition }=\frac{A c-A s}{A c} \times 100
$$

where: Ac is the absorbance of control test and As is the absorbance in the presence of the sample.

Reducing power assay

The reducing power of the extracts was determined according to procedure by Jayanthi et al. [14]. The absorbance of the resulting solution was registered at $700 \mathrm{~nm}$ against a blank to determine the amount of ferric ferrocyanide (Prussian blue) formed. AA was used as standard.

Measurement of ferrous ion chelating ability

The ferrous ion chelating activity of extracts was measured by the decrease in absorbance at $562 \mathrm{~nm}$ of the iron (II)-ferrozine complex according to the procedure described in our previous study [13]. The ability of the extracts to chelate ferrous ions was calculated using Equation 1.
The protective effect against hydroxyl radical induced DNA damage

The protective effect of $P$. cyclopium and $P$. brevicompactum extracts against hydroxyl radicalinduced DNA damage was assessed using with calf thymus DNA (Sigma - Aldrich, USA) as previously described by Lin et al. [16] with minor modifications. Briefly, the sample was dissolved in methanol at 1 $\mathrm{mg} / \mathrm{mL}$. Different concentrations of the extracts (31, $62,125,250$ and $500 \mu \mathrm{g} / \mathrm{mL}$ ) were then separately evaporated to dryness in Eppendorf tubes. $45 \mu \mathrm{L}$ of phosphate buffer $(0.2 \mathrm{~mol} / \mathrm{L}, \mathrm{pH} 7.4)$ were added to the sample residue. Subsequently, $5 \mu \mathrm{L}$ calf thymus DNA solution $(5 \mathrm{mg} / \mathrm{mL} \mathrm{NaCl}), 0.9 \mu \mathrm{L} 180 \mu \mathrm{mol} / \mathrm{L}$ $\mathrm{FeSO}_{4}$ and $3.6 \mu \mathrm{L} 600 \mu \mathrm{mol} / \mathrm{L}$ hydrogen peroxide were added in each test tube. After incubation at room temperature for $15 \mathrm{~min}, 10 \mu \mathrm{L}$ of $1 \mu \mathrm{mol} / \mathrm{L}$ EDTA was added to stop the reaction. The blank was the calf thymus DNA solution. Each $5 \mu \mathrm{L}$ aliquot of the reaction mixture was applied on $1 \%$ agarose gel containing ethidium bromide $(10 \mathrm{mg} / \mathrm{mL})$. The electrophoresis was conducted in $1 \mathrm{x}$ triethanolamine (TEA) buffer $\mathrm{pH} 8.0$ for $15 \mathrm{~min}$ at room temperature. The gel was then visualized using UV trans-illuminator (Vilber Lourmat) at $312 \mathrm{~nm}$ and photographed. DNA bands intensity was quantified using ImageJ software version 1.48 for Windows.

\section{Statistical analysis}

All experiments were performed in triplicate. There were tested the normality of distribution, means and standard deviations by Student t-test at the level of significance 0.05 and 0.01 . The correlation coefficient was analysed through Pearson's correlation coefficient. The $\mathrm{IC}_{50}$ values were calculated by nonlinear regression analysis from the sigmoidal dose-response inhibition curve. For statistical analysis, the SPSS software program version 13.0 for Windows was used.

\section{Results and Discussion}

The mycochemical screening of studied mycelia revealed the presence of mycochemicals considered as active medicinal chemical constituents. Mycochemicals such as phenols, terpenoids, tannins, alkaloids, amino acids and carbohydrates were found in both fungal extracts, as presented in Table I. On the other hand, flavonoids and saponins were not found. The presence of primary metabolites such as carbohydrates and amino acids in the tested extracts revealed that they can be used as good nutritional supplements [26]. Also, the other mycochemical compounds detected in the extracts are known to have a beneficial use in the pharmaceutical industry. The phenolics have got much attention in the day-to-day life due to their antimutagenic, antitumor and antioxidant activities [20]. The terpenoids display a wide range of biological activities such as anticancer and anti-inflammatory actions and are effective against infective agents such 
as viruses, bacteria and parasites. Several terpenoids have been reported to have trypanocidal and leishmanicidal activities [31]. Tannins were reported to exhibit antiviral, antibacterial and antitumor activities. It was also reported that certain tannins are able to inhibit HIV replication selectively and are also used as a diuretic. Many alkaloids are used in therapeutics and as pharmacological approaches. A wide range of biological effects has been reported for alkaloids, including emetic, anticholinergic, antitumor, diuretic, sympathomimetic, antiviral, antihypertensive, hypno-analgesic, antidepressant, myorelaxant, anti-tussigen, antimicrobial and anti-inflammatory activities [29].

Table I

Preliminary mycochemical analysis of ethanolic extracts of fungi

\begin{tabular}{lcc}
\hline Mycochemicals & $\begin{array}{c}\boldsymbol{P} \text {. } \\
\text { cyclopium }\end{array}$ & $\begin{array}{c}\boldsymbol{P} \text {. } \\
\text { brevicompactum }\end{array}$ \\
\hline Tannins & + & + \\
Flavonoids & & - \\
Terpenoids & - & + \\
Saponins & - & - \\
Steroids & + & + \\
Carbohydrates & + & + \\
Alkaloids & + & + \\
Phenols & + & + \\
Amino acids & + & + \\
"+" indicates the presence of mycochemicals; "-" indicates the
\end{tabular}

"+" indicates the presence of mycochemicals; "-" indicates the absence of mycochemicals

As the phenolic compounds represent the main antioxidant components derived from fungi, the determination of antioxidant capacity in various studies has mainly focused on these compounds. The bioactivity of phenolics may be associated with

their ability to chelate metals, inhibit lipoxygenase and scavenge free radicals [4]. Therefore, the total phenolic content in extracts of the tested fungi was quantitatively determined. The obtained results showed that both fungi possess a high amount of phenolics (Table II). Between the extracts analysed, the ethanolic extract of $P$. cyclopium showed higher TPC $(7.8 \mathrm{mg}$ GAE $/ \mathrm{g})$ compared to P. brevicompactum $(6.02 \mathrm{mg}$ $\mathrm{GAE} / \mathrm{g})$. Statistically, these two extracts showed significant differences of TPC values $(\mathrm{p}<0.05)$. The obtained results are in good agreement with literature data about TPC among different Penicillium sp. Precisely, the total phenolic content found in a few fungi species of the genus Penicillium is varied from $7.01 \mathrm{mg} \mathrm{GAE} / \mathrm{g}$ (P. granulatum) to $1 \mathrm{mg} \mathrm{GAE} / \mathrm{g}$ (some endophytic species). On the other hand, one isolate of Penicillium PR 46 possessed even $20.59 \mathrm{mg}$ GAE/g [30]. According to Jakovljević et al. [13], wastewater isolates $P$. chrysogenum $(2.86 \mathrm{mg} \mathrm{GAE} / \mathrm{g}$ ) and $P$. funiculosum $(2.11 \mathrm{mg} \mathrm{GAE} / \mathrm{g}$ ), cultivated in the same experimental conditions, had significant smaller amounts of TPC compared to fungi investigated in the current study. Apparently, the TPC of fungi grown in the same experimental conditions depends on the fungi species, i.e. their genetic basis. In addition, phenolics are produced by different pathways; therefore, different combinations of regulatory genes could mediate divergent responses under the same environment conditions [33]. These observations are also in agreement with results of O'Connor [21] who revealed that secondary metabolism of plants originated from di erent locations and habitats is under tight genetic control. Thus, the evaluation of phenolics content of each individual fungal species is very significant and justified.

Table II

Total antioxidant activity and total phenols contents of the extracts

\begin{tabular}{lcc}
\hline Ethanolic extract of fungi & Total antioxidant activity $(\mu \mathrm{g} \mathrm{AA} / \mathrm{g})$ & Total phenolic content $(\mathrm{mg} \mathrm{GAE} / \mathrm{g})$ \\
\hline P. cyclopium & $4.74 \pm 1.48^{\mathrm{a}}$ & $7.80 \pm 0.65^{\mathrm{a}}$ \\
P. brevicompactum & $7.79 \pm 1.39^{\mathrm{b}}$ & $6.02 \pm 0.82^{\mathrm{b}}$
\end{tabular}

Results are expressed as mean values \pm SD from 3 independent experiments. ${ }^{\mathrm{a}, \mathrm{b}}$ Means in the same column with superscript with different letters are significantly different $(\mathrm{p}<0.05)$

The total antioxidant capacity of fungal extracts, expressed as the number of $g$ equivalents of ascorbic acid, is shown in Table II. The ethanolic extract of $P$. brevicompactum showed the highest total antioxidant capacity $(7.79 \mu \mathrm{g} \mathrm{AA} / \mathrm{g})$ which was identical to the antioxidant capacity of AA. On the other hand, P. cyclopium showed approximately a 1.5fold lower capacity (4.74 $\mu \mathrm{g} \mathrm{AA} / \mathrm{g}$ ) compared to $P$. brevicompactum. The current results are far better than those of $P$. chrysogenum and $P$. funiculosum obtained in previous studies [13]. The statistical analysis showed significant differences among the tested extracts considering TOA $(p<0.01)$. The relationship between TPC and TOA was investigated by Pearson's correlation. This statistical data (Table IV) showed a very strong negative correlation between TPC and TOA $(r=-0.999, p<0.01)$. The obtained result suggests that the antioxidant capacity of the tested fungi may be caused by the presence of nonphenolic compounds, which can act synergistically or antagonistically with various phenols in the extract. Also, it should be taken into consideration that different phenolic compounds may show different antioxidant activities, depending on their structure. Even more, simple phenols, despite of the fact that they are not effective antioxidants, react with FolinCiocâlteu reagent.

The DPPH radical-scavenging capacity of fungi is expressed as $\mathrm{IC}_{50}$ value, defined as the concentration of antioxidant required for scavenging $50 \%$ of DPPH 
FARMACIA, 2018, Vol. 66, 3

radicals. The $\mathrm{IC}_{50}$ values of ethanolic extract of both fungi and some positive controls are shown in Table III. The both ethanolic extracts had low scavenger activity against DPPH radicals, with $\mathrm{IC}_{50}$ values 1253 and $1375 \mu \mathrm{g} / \mathrm{mL}$ for $P$. brevicompactum and $P$. cyclopium, respectively. In relation to commercial antioxidants, the DPPH radical scavenging ability of the extracts was significantly inferior. Comparing the obtained results with relevant studies in published literature, it was concluded that $P$. brevicompactum and $P$. cyclopium had a lower ability of inhibition DPPH free radicals than $P$. citrinum [23] and $P$. granulatum [2]. However, the DPPH scavenger activity of the tested extracts was better than the activity of $P$. chrysogenum and very similar to $P$. funiculosum [13]. According to statistics, a very strong correlation $(\mathrm{r}=0.997, \mathrm{p}<0.01)$ was found between TPC and the DPPH scavenging activity expressed as $\mathrm{IC}_{50}$ value. This finding indicates that phenolic compounds of the tested fungi are the main contributors of their antioxidant activity. This result is in agreement with results of other researchers [26]. For DPPH scavenging activity and TOA a very strong negative correlation $(\mathrm{r}=-0.999, \mathrm{p}<0.01)$ was found (Table IV). In spite of that, it is evident that both extracts showed proton-donating ability and thus could serve as free radical inhibitors or scavengers.

The $\mathrm{IC}_{50}$ values of antioxidant activities of the ethanolic extracts of $P$. brevicompactum and $P$. cyclopium, and some natural and synthetic antioxidants

\begin{tabular}{lcccc}
\hline \multicolumn{1}{c}{$\begin{array}{c}\text { Ethanolic extract of } \\
\text { fungi/standards }\end{array}$} & \multicolumn{3}{c}{$\mathrm{IC}_{50}(\mu \mathrm{g} / \mathrm{mL})$} \\
\cline { 2 - 5 } & $\begin{array}{c}\text { DPPH scavenging } \\
\text { activity }\end{array}$ & $\begin{array}{c}\text { Metal chelating } \\
\text { activity }\end{array}$ & Reducing power & $\begin{array}{c}\text { Protective effect against hydroxyl-induced } \\
\text { DNA damage }\end{array}$ \\
\hline P. cyclopium & $1375 \pm 2.18^{\mathrm{f}}$ & $68 \pm 0.10^{\mathrm{a}}$ & $212 \pm 0.25^{\mathrm{a}}$ & $23 \pm 0.02^{\mathrm{a}}$ \\
P. brevicompactum & $1253 \pm 1.63^{\mathrm{e}}$ & $146 \pm 0.55^{\mathrm{b}}$ & $650 \pm 0.42^{\mathrm{b}}$ & $26 \pm 0.02^{\mathrm{a}}$ \\
GA & $3.97 \pm 0.10^{\mathrm{ab}}$ & nd & nd & $59.14 \pm 1.15^{\mathrm{c}}$ \\
AA & $6.05 \pm 0.12^{\mathrm{ac}}$ & $352.9 \pm 1.25^{\mathrm{d}}$ & $881 \pm 0.15^{\mathrm{c}}$ & $160.60 \pm 2.35^{\mathrm{d}}$ \\
BHT & $362 \pm 0.84^{\mathrm{d}}$ & $>1500^{\mathrm{f}}$ & nd & $34 \pm 1.00^{\mathrm{b}}$ \\
$\alpha$-tocopherol & $12 \pm 0.33^{\mathrm{c}}$ & $>1000^{\mathrm{c}}$ & nd & nd \\
Quercetin & $1.48 \pm 0.29^{\mathrm{bc}}$ & $550 \pm 1.18^{\mathrm{e}}$ & nd & nd \\
\hline
\end{tabular}

GA - gallic acid, AA - ascorbic acid, BHT - butylated hydroxytoluene, nd - not determined. Results are expressed as mean values \pm SD from 3 independent experiments. ${ }^{\mathrm{a}, \mathrm{b}, \mathrm{c}, \mathrm{d}, \mathrm{e}, \mathrm{f}}$ Means in the same column with superscript with different letters are significantly different $(\mathrm{p}<0.05)$

Results concerning the reducing power ability of ethanolic mycelial extracts and natural compound (AA) are presented in Table III. Antioxidant compounds that act as reducing agents exert their effect by donating a hydrogen atom to ferric complex and thus break the radical chain reaction. The ethanolic extract of $P$. brevicompactum showed a significant higher (about 3-fold) activity with $\mathrm{IC}_{50}=650 \mu \mathrm{g} / \mathrm{mL}$ than the extract of $P$. cyclopium with $\mathrm{IC}_{50}=212 \mu \mathrm{g}$ / $\mathrm{mL}$. The results of the current study in terms of the ferric reducing antioxidant potential are in agreement with the results of Arora and Chandra [2]. According to the mentioned authors, the reducing power of several Penicillium soils isolates was variable (from $0.298 \mathrm{mg} / \mathrm{mL}$ to $1.08 \mathrm{mg} / \mathrm{mL}$ ). The good reducing power ability of $P$. brevicompactum is in line with reducing power of wastewater isolates $P$. funiculosum and $P$. chrysogenum [13]. However, the reducing power of both $P$. brevicompactum and $P$. cyclopium extracts was significant lower compared to the natural antioxidant $\mathrm{AA}\left(\mathrm{IC}_{50}=881 \mu \mathrm{g} / \mathrm{mL}\right)$, which is known to be a strong reducing agent. The correlation between reducing power activity of fungi and their TPC was found to be very strong and negative $(\mathrm{r}=$ $-0.999, p<0.01$ ), as Table IV shows. Conversely, a very strong positive correlation was noted between their reducing power and TOA $(r=1.000, p<0.01)$, as well as between the reducing power and the metal chelating activity $(r=0.907, p<0.05)$. Taking into consideration $r$ values, these results suggested that phenols play an important role in the reducing power (electron-donating activity) of fungi.

Generally, iron is an essential element for living organisms on the one hand, but its excess may lead to accumulation of highly reactive radicals, on the other side. Ferrous ions are involved in the conversion of superoxide anion radical and hydrogen peroxide into the more reactive hydroxyl radical and these ROS may oxidize different cell components (lipids, proteins, DNA) [19]. These processes can be delayed by iron chelation and deactivation. The results of ferrous ion chelating activity of ethanolic extract of $P$. brevicompactum and $P$. cyclopium as well as some natural and synthetic antioxidants are summarized in Table III. Both ethanolic extracts demonstrated remarkable ferrous ion chelating capacity, much better compared to synthetic compounds (Table III). Among the two fungal extracts analysed, the ethanolic extract of $P$. cyclopium showed superior ferrous ion chelating capacity with lower $\mathrm{IC}_{50}=68 \mu \mathrm{g} / \mathrm{mL}$ than the extract of $P$. brevicompactum $\left(\mathrm{IC}_{50}=146 \mu \mathrm{g} / \mathrm{mL}\right)$. The $\mathrm{IC}_{50}$ value of the ferrous ion chelating capacity of $P$. cyclopium is very similar to those of $P$. funiculosum $\left(\mathrm{IC}_{50}=46 \mu \mathrm{g} / \mathrm{mL}\right)$ and $P$. chrysogenum $\left(\mathrm{IC}_{50}=48 \mu \mathrm{g} / \mathrm{mL}\right)$ obtained in the study of Jakovljević et al. [13]. As Table III shows, commercial antioxidants showed weak ferrous ions chelating ability, especially BHT and $\alpha$-tocopherol, compared 
FARMACIA, 2018, Vol. 66, 3

to both extracts. The correlation between TPC and metal chelating activity expressed as $\mathrm{IC}_{50}$ value was found to be very strong and negative $(r=-1.000$, $\mathrm{p}<0.01)$. Likewise, a strong positive correlation was found between $\mathrm{IC}_{50}$ values of ferrous ions chelating and TOA. As Table IV shows, a low correlation ( $\mathrm{r}=$ $-0.554, \mathrm{p}<0.05$ ) was found between $\mathrm{IC}_{50}$ values of ferrous ions chelating and DPPH radical scavenging activities. Obviously, this great activity of extracts is in accordance with its high TPC.

Table IV

The Pearson's correlation coefficients ( $\mathrm{r}$ ) between total phenolic contents and antioxidant activities of the

extracts

\begin{tabular}{|c|c|c|c|c|c|c|}
\hline TPC vs. antioxidant activities & $\mathrm{TPC}^{\mathrm{a}}$ & $\mathrm{TOA}^{\mathrm{b}}$ & $\mathrm{DPPH}^{\mathrm{c}}$ & $\mathrm{MCA}^{\mathrm{d}}$ & $\mathrm{RP}^{\mathrm{e}}$ & $\cdot{ }^{-O H}$-induced DNAdamage ${ }^{f}$ \\
\hline $\mathrm{TPC}^{\mathrm{a}}$ & 1.000 & & & & & \\
\hline $\mathrm{TOA}^{\mathrm{b}}$ & $-0.999 * *$ & 1.000 & & & & \\
\hline $\mathrm{MCA}^{\mathrm{d}}$ & $-1.000^{* *}$ & $1.000 * *$ & $-0.554 *$ & 1.000 & & \\
\hline $\mathrm{RP}^{\mathrm{e}}$ & $-0.999 * *$ & $1.000 * *$ & $-0.812 * *$ & $0.907 * *$ & 1.000 & \\
\hline -OH-induced DNAdamage ${ }^{f}$ & $-0.671 * *$ & $0.939 * *$ & $-0.671 * *$ & -0.100 & $0.773 * *$ & 1.000 \\
\hline
\end{tabular}

The protective effects of $P$. cyclopium and $P$. brevicompactum ethanolic extracts on calf thymus DNA damage due to the oxidative stress were investigated for the first time in the current study. The obtained results showed that ethanolic extracts of both fungi were able to reduce the hydroxyl radical-induced damage in calf thymus DNA in a dose-dependent manner (Figure 1). The results showed the degradation of calf thymus DNA treated with Fenton's reagent (line 7) compared to control (DNA, line 1). The action of fungal extracts on the DNA damage caused by $\bullet \mathrm{OH}$ was indicated from line 1 to line 6. As Figure 1 shows, incubation of DNA with $\mathrm{FeSO}_{4}$ and $\mathrm{H}_{2} \mathrm{O}_{2}$ for 15 min at room temperature resulted in high percentage of DNA damage from $66 \%$ (a) to $73 \%$ (b), which means a 2.90 - and 3.71 - fold increase compared to control. However, the intensity of the DNA damage was reduced on a concentration dependent manner by the fungal ethanolic extracts towards, which shows the protective effect of the extracts towards hydrogen peroxide induced damage. The protective effect of the extract of $P$. brevicompactum on DNA damage was significantly stronger than $P$. cyclopium. At the concentration of the $P$. brevicompactum extract used $(250 \mu \mathrm{g} / \mathrm{mL})$, the DNA damage was almost not detectable, with a high intensity DNA band similar to the control, but in the case of $P$. cyclopium the same effect was obtained at the maximum concentration of the extract $(500 \mu \mathrm{g} / \mathrm{mL})$.

As Figure 1 shows, both extracts used at a lower concentrations did not show a statistically significant difference, because their $\mathrm{IC}_{50}$ values are very uniform (26 $\mu \mathrm{g} / \mathrm{mL}$ and $23 \mu \mathrm{g} / \mathrm{mL}$ ), but in relation to the standards (GA, AA, and BHT) they showed statistically significant differences $\left(\mathrm{IC}_{50}=59.14,160.60\right.$ and 34 $\mu \mathrm{g} / \mathrm{mL})$. These results clearly indicate that both extracts used are very potent antioxidants even in low concentrations; 2 - to 5-fold more powerful than the applied synthetic antioxidants (Table III).

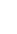

$\begin{array}{lllllll}1 & 2 & 3 & 4 & 5 & 6 & 7\end{array}$

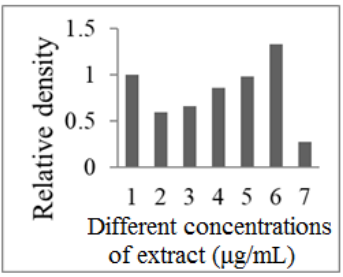

Figure 1.
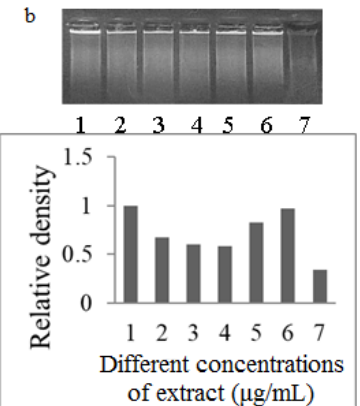

of extract $(\mu \mathrm{g} / \mathrm{mL})$

Protective effect of ethanolic extract of $P$. brevicompactum (a) and $P$. cyclopium (b) on hydroxyl radical mediated DNA strands breaks. Line 1, normal DNA (control group); Line 2 - 6, different concentrations of extracts $(31,62,125,250$ and $500 \mu \mathrm{g} / \mathrm{mL})$; Line 7 , DNA damage model group

Such high DNA protective activity is in accordance with the antioxidant activity of fungi, as Table IV shows. Statistical data showed a negative correlation $(\mathrm{r}=-0.943, \mathrm{p}<0.01)$ between the DNA protective effect and TPC of extracts. A correlation was found between the DNA protective effect and TOA $(\mathrm{r}=$ $0.939, \mathrm{p}<0.01)$ and a moderate correlation between the DNA protective effect and the reducing power of extracts $(r=0.773, p<0.05)$. Again, taking into account the $r$ values, these results suggested that phenols play an important role in protecting the DNA structure from hydrogen peroxide induced damage.

\section{Conclusions}

This is the first study focused on the mycochemical screening, antioxidative potential and DNA protection against hydroxyl radical damage of $P$. cyclopium and $P$. brevicompactum isolated from sewage wastewater. Both ethanolic extracts are a source of primary (amino acids, carbohydrates) and secondary metabolites (phenols, terpenoids, alkaloids and tannins) with significant antioxidant activity. The ethanolic extract 
of $P$. cyclopium contained the highest amount of total phenols and ferrous ion chelating ability whereas $P$. brevicompactum showed the highest total antioxidant capacity, DPPH free-radical scavenging activity as well as reducing power. Also, the obtained results showed that the ethanolic extracts of mycelia were able to reduce the hydroxyl radical-induced DNA damage in a dose-dependent manner. The current study provides data for supporting the use of the tested fungi as natural antioxidant agents. However, detailed studies on the role of individual mycochemicals involved in the antioxidant activity of fungi are required for their practical use in food, pharmaceutical, agricultural and environmental industry. Future research will be focused in this direction.

\section{References}

1. Arora DS, Chandra P, Kaur GJ, Optimization and assay of antioxidant potential of two Penicillium spp. Curr Biotechnol., 2012; 1: 2-10.

2. Arora DS, Chandra P, In vitro antioxidant potential of some soil fungi: screening of functional compounds and their purification from Penicillium citrinum. Appl Biochem Biotechnol., 2011; 165: 639-651.

3. Baskaran N, Rajasekaran D, Manoharan S, Coumarin protects 7,12-dimethylbenz(a)anthracene-induced genotoxicity in the bone marrow cells of golden Syrian hamsters. Int J Nutr Pharmacol Neurol Dis., 2011; 1: 167-173.

4. Bhatt V, Bhati GS, Gupta S, Evaluation of free radical scavenging behaviour and antioxidant activity in various citrus fruits. EJAET, 2016; 3: 40-44.

5. Chai TT, Wong FC, Whole-plant profiling of total phenolic and flavonoid contents, antioxidant capacity and nitric oxide scavenging capacity of Turnera subulata. J Med Plants Res., 2012; 6: 1730-1735.

6. Chandra P, Arora DS, Optimization of antioxidant potential of Penicillium granulatum bainier by statistical approaches. ISRN Microbiology, 2012; 2012: 1-10.

7. Cheng N, Ren N, Gao H, Lei X, Zheng J, Cao W, Antioxidant and hepatoprotective effects of Schisandra chinensis pollen extract on CCl4-induced acute liver damage in mice. Food Chem Toxicol., 2013; 55: 234-240.

8. El-Sherif G, El-Sherif MA, Tolba KH, Extraction and identification of natural antioxidants from liquorices (Glycyrrhiza glabra) and carob (Ceratonia siliqua) and its application in El-Mewled El-Nabawy sweets (Sesames and Folia). Nat Sci., 2011; 9: 108-115.

9. Golla U, Bhimathati SSR, Evaluation of antioxidant and DNA damage protection activity of the hydroalcoholic extract of Desmostachya bipinnata L. Stapf. Scientific World Journal, 2014; 2014: 1-8.

10. Gurung N, Ray S, Bose S, Rai V, A broader view: microbial enzymes and their relevance in industries, medicine, and beyond. Biomed Res Int., 2013; 2013: 1-18.

11. Hina MI, Dhanapal S, Sekar DS, Studies on antibacterial activity of some fungi collected from K.R.P
Dam, Krishnagiri (TN). Int J Eng Res Manage., 2015; 2 : 1-2.

12. Ibrahim DI, Muhammad I, Ashiru S, Sani I, Shehu K, Aliero RAA, Aliyu, Qualitative and quantitative phytochemical screening of Mimoso Pudica plant extracts (touch me not). Am J Biological Chem., 2014; 2: 8-16.

13. Jakovljević VD, Milićević JM, Stojanović JD, Solujić SR, Vrvić MM, Antioxidant activity of ethanolic extract of Penicillium chrysogenum and Penicillium fumiculosum. Hem Ind., 2014; 68: 43-49.

14. Jayanthi $P$, Lalitha $P$, Reducing power of the solvent extracts of Eichhornia crassipes (mart.) Solms. Int J Pharm Pharm Sci., 2011; 3: 126-128.

15. Kalpana KB, Devipriya N, Srinivasan M, Vishwanathan $\mathrm{P}$, Thayalan K, Menon VP, Evaluating the radioprotective effect of hesperidin in the liver of Swiss albino mice. Eur J Pharmacol., 2011; 658: 206-212.

16. Lin J, Li X, Chen L, Lu W, Chen X, Han L, Chen D, Protective effect against hydroxyl radical-induced DNA damage and antioxidant mechanism of (6)gingerol: A chemical study. Bull Korean Chem Soc., 2014; 35: 1633-1638.

17. Madaan R, Bansal G, Kumar S, Sharma A, Estimation of total phenols and flavonoids in extracts of Actaea spicata roots and antioxidant activity studies. Indian J Pharm Sci., 2011; 73: 666-669.

18. Mendes V, Vilaça R, de Freitas V, Ferreira PM, Mateus N, Costa V, Effect of myricetin, pyrogallol, and phloroglucinol on yeast resistance to oxidative stress. Oxid Med Cell Longev., 2015; 2015: 1-10.

19. Naithani V, Singhal AK, Chaudhary M, Comparative evaluation of metal chelating, antioxidant and free radical scavenging activity of TROIS and six products commonly used to control pain and inflammation associated with Arthritis. Int J Drug Dev \& Res., 2011; 3: 208-216.

20. Negi JS, Singh P, Rawat B, Chemical constituents and biological importance of Swertia: a review. Curr Res Chem., 2011; 3: 1-15.

21. O'Connor SE, Engineering of secondary metabolism. Annu Rev Genet., 2015; 49: 71-94.

22. Olugbami JO, Gbadegesin MA, Odunola OA, In vitro free radical scavenging and antioxidant properties of ethanol extract of Terminalia glaucescens. Pharmacognosy Res., 2015; 7: 49-56.

23. Pushpalatha HG, Sudisha J, Geetha NP, Amruthesh KN, Shetty HS, Thiamine seed treatment enhances LOX expression, promotes growth and induces downy mildew disease resistance in pearl millet. Biol Plantarum, 2011; 55: 522-527.

24. Raja K, Ravindranadh K, Phyto, phytochemical standardization and TLC fingerprinting of medicinal plant Couroupita guianensis. Int J Phytomedicine, 2014; 6: 587-594.

25. Safiyanu I, Abdulwahid Isah A, Abubakar US, Rita Singh M, Review on comparative study on bioremediation for oil spills using microbes. RJPBCS, 2015; 6: 783-790.

26. Sajeesh T, Arunachalam K, Parimelazhagan T, Antioxidant and antipyretic studies on Pothos scandens L. Asian Pac J Trop Dis., 2011; 4: 889-899. 
27. Sharma S, Ahmad A, Gupta S, Phytochemical and antioxidant activity of ethanolic bark extract of Nyctanthesar bortristis Linn. IPP, 2013; 1: 172-184.

28. Sheikhlar A, Alimon AR, Daud HM, Saad CR, Shanagi H, Screening of Morus alba, Citrus limon and Trigonella foenum-graecum extracts for antimicrobial properties and phytochemical compounds. J Biol Sci., 2013; 13: 386-392.

29. Souto AL, Tavares JF, da Silva MS, Diniz MFFM, de Athayde-Filho PF, Filho JMB., Anti-inflammatory activity of alkaloids: an update from 2000 to 2010 . Molecules, 2011; 16: 8515-8534.

30. Subha K, Baskar V, Kanimozhi K, Panneerselvam $\mathrm{A}$, In vitro investigation on antioxidant activity of terrestrial and marine Penicillium chrysogenum strain. Int $J$ Res Pure Applied Microbiology, 2015; 5: $1-5$.

31. Sülsen VP, Cazorla SI, Frank FM, Laurella LC, Muschietti LV, Catalán CA, Natural terpenoids from Ambrosia species are active in vitro and in vivo against human pathogenic trypanosomatids. PLoS Negl Trop Dis., 2013; 7: 1-10.

32. Tajick MA, Seid MKH, Babaeizad V, Identification of biological secondary metabolites in three Penicillium species, $P$. goditanum, $P$. moldavicum and $P$. corylophilum. Prog Biol Sci., 2014; 4: 53-61.

33. Watson RR (Ed.): Polyphenols in plants: Isolation, purification and extract preparation, College of Public Health, University of Arizona, Tucson, USA, 2014.

34. Zhang Y, Guo J, Qi Y, Shao Q, Liang J, The prevention of radiation-induced DNA damage and apoptosis in human intestinal epithelial cells by salvianic acid A. J Radiat Res Appl Sci., 2014; 7: 274-285.

35. Zhelifonova VP, Antipova TV, Kozlovsky AG, Secondary metabolites in taxonomy of the fungi. Mikrobiologiya, 2010; 79: 291-300. 